\title{
The Impact of Training on the Employees' Career Path Development Case of the Algerian company: Oran Port Enterprise
}

https://doi.org/10.21272/sec.5(3).28-42.2021

Miss Bessaim Radia, ORCID: https://orcid.org/0000-0002-8551-6844

Doctoral Student, University Oran 2, Algeria

Mrs Gadi Ibtissem, ORCID: https://orcid.org/0000-0002-9713-0359

Lecturer “A”, University ORAN 2, Algeria

\begin{abstract}
This paper aimed to clarify the role that the training employees' plays on the development of their career path in the company, training becomes a tool that company must use it to improve their performance and so achieve their goals, it becomes an investment in Human Resources! This study focused on two sides, the steps of training in the Oran Port Enterprises especially determination of training needs which is the most important step to develop the competency of employees, and the career path improvement in this company. The purpose of this article is answer the main question of the study which is to know how training contributes in the career path development of employees, and which can affect the performance of the Algerian company: Oran Port Enterprise. Firstable, we counted on the stages of scientific research by gathering information about the Oran Port Enterprise, after that we chose our sample; we elaborated the questionnaire to answer the questions. Secondly, we analysed the process of training in this company. Our sample contained 50 employees, we relied the descriptive analytical approach, a set of tools were used which is: observation, interview guide, questionnaire, in addition to the internal documents, the result of study assured that training contributes to drawing employees' career path, by gaining knowledge and experience and thus occupying several positions and jobs in the company, the study concluded the following recommendations: providing sufficient period to train employees, involve all stakeholders in the process of designing the training plan, relying on training as basis for promotion and internal recruitment, and thus reducing costs. Finally, we have reached that training is an investment in human resources in the medium-and long-term, and it allows adapting with transformations and organizational changes in the level of external environment and within organization.
\end{abstract}

Keywords: training, career path, competency, human resources, Oran Port Enterprise.

JEL Classification: L32, M53, M54, J24.

Cite as: Bessaim Radia, B., Gadi Ibtissem (2021). The Impact of Training on the Employees' Career Path Development Case of the Algerian company: Oran Port Enterprise. SocioEconomic Challenges, 5(3), 28-42. https://doi.org/10.21272/sec.5(3).28-42.2021.

Received: 04.06.2021

Accepted: 03.09 .2021

Published: 13.09 .2021

Copyright: (C) 2021 by the authors. Licensee Sumy State University, Ukraine. This article is an open access article distributed under the terms and conditions of the Creative Commons Attribution (CC BY) license (https://creativecommons.org/licenses/by/4.0/).

\section{Introduction}

The world is evolving, everything is fast-changing! The contemporary companies have recognized the importance of the human resources and its contributions in adaptation with the environment changes in order to insure its existence in the market, and keep it growing so as to achieve competitive advantage, it is therefore important to invest in human resources as a key factor in improving performance in the companies on the one hand, besides creating an competent group on the other. 
Companies therefore seek to develop their human resources and extract all energies and skills from them, one of the main tool used by the companies to face technological and economic mutations, and develop its competencies and quality- making is training which is considered a tool that can develop and improve skills and competencies, and access to real-time, renewable information that has a direct impact on efficiency and effectiveness, and because it's important for company, it is also a basic source of motivation, and internal communication improvement, so it create a positive business atmosphere based on trust and empowerment, more importantly, it's a way to develop their career paths, training contributes to promotion, and thus to increased remuneration, transfer or conversion, achieve an advancement in the company, or creating a polyvalent human resource, and it's an important station in the career path for employees, this results of training show us the need to invest in human resources as a necessity operation to develop the staff and so all organization.

Our study aims to clarify the role of training in improvement of career path of employees in an Algerian company "Oran Port Enterprise" and its impact on performance of employees.

In view of the foregoing, we are going to answer the question: Does training contribute to developing and improving the career path of the employees in the Algerian company?

Branching from the main question, the following questions:

$>$ What is the meaning of training for employees of Oran Port Enterprise? And what role does it play in this company?

$>$ Does the training provide the added value to the employees in Oran Port Enterprise to improve their career path?

\section{Study hypothesis}

Depending on the study question, the main hypotheses were formulated, which are the most logical probability to answer the question, and they are as follows:

$>$ There is a correlation between training and career path.

$>$ Training contributes to improving the career path of employees in the Algerian company in general and in Oran Port Enterprise in particular.

$>$ The sub-hypothesis was as follows:

$>$ Training contributes to the development of positive trends of workers towards work, so that training means acquiring knowledge and experience for employees, it is important tool for motivating, empowering, and improving the internal communication of the organization, thus creating an atmosphere of trust within organization.

$>$ Training allows the development of employees' competency, in addition it affects their effectiveness and efficiency in carrying out the tasks entrusted to them, and as a result the development of their career path through promotion, assuming multiple positions and responsibilities.

The importance of the study represented in:

The theoretical side: the importance of the study is to link the training activity, which is among the main activities of human resources management, and the career path of the employees in the company, because understanding the relationship between training and career path, which is absolutely positive relation, because it happens on two levels organization and employees, that training can achieve the strategic goals through efficiency and effectiveness improvement of the employees which are in turn reflected in the performance of the organization, furthermore it can be a tool that help to improve and develop competencies and obtain a motivating human resources in the other hands, consequently, all these factors contribute in improvement of the organizational behaviour.

The practical side: the importance of the practical aspect is to come up with results that lead us to present suggestions and recommendations to organizations in general and to Oran Port Enterprise in particular, enabling 
it to respond to its aspirations and the aspirations of its employees, and to know the importance of training in the Algerian company as an essential activity that concerns to develop the performance and competencies in addition to improve the organizational behaviour of the employees and companies both.

\section{Methodology}

Based on the nature of the study and the informations to be obtained to study the role of training in improving the career path of employees in the Algerian company: Oran Port Enterprise, we will address in:

Theoretical aspect: by using the descriptive analytical approach to study the activities, the descriptive approach to present the phenomenon as it is, and express it in quantity and quality, the quantity express means using the numbers language, while the qualitative express is the one who describes the phenomenon and highlights its characteristics, and it does not stop there, but goes beyond it to the analytical approach, through the interpretation and linking between the factors related to the phenomenon to reach results and conclusions regarding the basic concept of this phenomenon studies, in the case of our study is to find the relationship between training and career path.

Practical aspect: according to the nature of the topic of the study, we will use study case in Oran Port Enterprise, to know the role of training in improvement of career path of employees, furthermore this will allow for a comparison between the theatrical concepts and the extent of their application in the Algerian company, and that's through using the questionnaire, and interview guide.

\section{The training in the Company: Definitions of the Concepts}

The topic of training is one of the topics that spilled a lot of ink lately, which is interests all scientific disciplines especially in the last three decades, where the eyes of researchers especially in the field of sociology and management sciences turned to this topic, especially after the developments that occurred in the human resources management, in Algeria for example the Algerian legislator has devoted several articles in law 90/11 related to work relations to training activity. This is not in vain, but in view of the great importance of training in contemporary organizations. There are a lot of authors who talk about training, that's why there are several definitions of training have been given:

According to Ivan Cevich "it is a systematic process to change the behavior of employees towards the development of the organization's goals, in the present and future" (Ivan Cevich, 1995, p. 423), this definition recognized that training contributes to the development of positive trends towards the company, and thus improve the level of effectiveness, and this is the main strategic objective of the company.

Training is a process of teaching new or current employees the basic skills they need to perform their jobs (Dessler, 2017, p. 235).

According to Roger Buckley and Jim Caple "training is a planned and systematic effort to modify or develop knowledge/skill/attitude through learning experience, to achieve effective performance in an activity or range of activities. Its purpose, in the work situation, is to enable an individual to acquire abilities in order that he or she can perform adequately a given task or job and realize their potential (BUCKLEY \& CAPLE, 2009, p. 9), this definition confirms that training allows acquiring knowledge, skills and abilities to perform the job, that what (Noe, R.Hollenbeck, Gerhart, \& Wright, 2016, p. 201) were agree with when they defined training as an organization's planned efforts to help employees acquire job-related knowledge, skills, abilities, and behaviors, with the goal of applying these on the job. This means training aims to adjust the gaps between acquired skills and required skills, and recognition of the potential of employees.

Training is a complex concept consisting of several elements, it means a change for the better, or a development in the individual's informations, abilities, skills, thoughts, behaviors and trends in order to prepare the individual well to meet the demands of current jobs and develop his or her technical and intellectual skills to meet future needs (others, 2018), this definition is more comprehensive and effective, where he took a range of cognitive and behavioral changes that are improved by the training, which leads to adapting to the current situation, and preparing for future changes, and this was confirmed by Werther that training is the efforts aimed at providing the individual worker with the informations and knowledge that gain skill to him in performing the work or 
developing skills, and experiences and knowledge towards increasing the current and future competencies of the working individual (Werther.B., 1982).

From the foregoing, we conclude that training is an activity of human resources management, which is have a great importance to both the organization and the employees, its important also exceeded from the position of work to the psychological aspect, as it brings together various aspects: behavioral, because it has a positive impact on individuals, the group, and organization as a whole, in order to improve the efficiency and effectiveness, and sense of job security, and also the knowledge aspect: through acquiring the necessary and relevant informations for the jobs and then the practical aspect: that is the use of knowledge acquired during work practice, which affects the quality of the goods or services and fill the existing knowledge gaps. Here we can say that training is the organization's investment in its human resources, to build and constituting a competent staff in the long-term to achieve their objectives.

\subsection{The Importance and Objectives of Training}

1.1.1. The importance of training. Organizations carry out the training process because of its importance in achieving their goals, which the employers know that training fosters engagement (DESSLER, 2020, p. 240), Dessler gave an example about that, which is very famous company Coca-Cola UK that uses employee development plans, training, and leadership development to attract and retain the best employees and inspire their engagement, so training take a big place to improve the performance of the imployees, furthermore the reputation of the company in the field of continiuos staff training which attracts the others especially the competent employee in the desire to work for the company. Ahmed Sayed Mustafa also indicated that the employee will need to acquire new knowledge and skills on average at least eight times during his career path (NASSR, 2017, p. 25).

Training and development safeguards such productivity as well as supporting it by preparing employees for future jobs and insulating firms from skills shortages, when jobs can be filled internally, firms are less dependent on the outside labor market and do not risk appropriate recruits not being available (or not available at the price the organization wished to pay) such security is welcome (WILKINSON, REDMAN, \& DUNDON, 2017, p. 133), the authors here give the big importance for training as a tool to recruit employees internally, as a result minimize the costs of recruitment in the hand, and to retain needed workers that have the competencies, which makes them feel secure within company, and they are part and parcel of the company, that creating a sense of membership that conducts to improve the positive organizational behavior, and create social climate based on trustful working relations and motivation, that can help in the development desire to improve the career path for employees.

According to (NASSR M. A., 2016, p. 22), the importance of training is that the organization adapts to rapid and pursuit technological changes, and increasing interest in improving product quality levels and the desire to increase productivity to facing the challenges of competition. This definition gave the place of the technological mutations to improve the quality of products, especially the desire to achieve the competitive advantage to rest in the market. While (MUSLIM, 2007) went further when he emphasized that the importance of training is very central, as it ensures the survival, continuity and development of the organization, and also helps the various actors in the organization to improve and develop performance, in addition, it plays a critical role in the promotion and the good management of human resources in general, and all of this is due to its direct relationship with:

- $\quad$ Selection and training.

- Capacity assessment system and needs inventory.

- With promotion inside or outside the job position.

- With continuous adaptation to the internal and external environment of the organization, the local and global.

This idea reinforced by (ACHOUCH, ALSAID, \& NAFSIA, 2017, p. 325) through the fact that training allows preparing the individual to carry out new tasks and providing him with intellectual, technical and behavioral skills for the basic requirements of the new job, this is due to the transfer and promotion of jobs, and therefore each job has its own responsibilities and burdens, training also reduces supervision, the employee be self-supervising, this resulting in reduced accidents and injuries at work. 
The importance of training is to help the employee aquire and maintain the necessary skills, capabilities and personal capacities to contribute more adequately to the attainmrnt of organizational and relational objectives (Gambo, 2015, p. 2)

To conclude the importance of training, we can say that training is one of the most important activities of human resources management, which allows to the employees to develop and improve their effectiveness throughout their careers in the organization, thus raising the productivity of the organization and improving its performance, which will reflect positively on the image of the company at the external level and within organization.

1.1.2. The objectives of training. Training can achieve a lot of objectives, that's why organizations organize the training programs to obtain these objectives the mainly one is to help the organization to achieve its mission and objectives through improved individual performance and thus improved organizational performance, it also seeks to give staff the knowledge, skills, abilities and trends required by their current jobs (ELBLOUCHI, 2017, pp. 165-166), while (MOUNIR, 2014, pp. 243-244) divided it into a set of goals:

Increase in the production: it is the increase in its quantity and quality by training the employees on how to master their work, and then increase their productivity. Here (CHARARAH, 2019, p. 165) was agreed with this view, which emphasized that training contributes to productivity enhancement and cost effectiveness, and reducing accidents and errors.

- $\quad$ Reducing turnover: as training and indoctrinates them with knowledge is that matches their perceptions increases their ability to carry out their jobs, it means creating a kind of stability and constancy in the lives of employees and their desire and ability to carry out their work.

The development of employees to do their tasks, and future jobs: training aims to increase the employee ability to the creative and innovative thought, (ALTAANI, 2007, p. 15) mentioned also that training enable the employee to adapt with his work on the one hand, and face his problems and overcome them on the other hand.

Furthermore, among the main objectives of the training is to change behaviors and trends, allowing the trainee to acquire a new values towards specific issues and situations (ALHITTI, 2005, p. 225).

We can say that training addresses the real problems of the employees, and it tries to solve it and reduces the gap between work needs and the real competency. Training seek not only the performance, but also and specially the behaviours and create a organizational culture based on exchange of the knowledge, and share experiences and positive values with the teamwork within organization.

1.2. Training from a legal according to the Algerian legislator. Training is compulsory activity that's mean all Algerian companies, institutions, enterprises with their deferent activities and sector must elaborate a training plan and this is annually, by allocating $01 \%$ of the wage mass to the training process, this is all determined in the Algerian act 90/11 of the employment relationship. Algeria's act No.11/90, dealt with all human resources functions, including training at work, and that's through the articles 57 to 60 , demonstrating that the employees must followed the training programs, to improve the performance $(90 / 11,1990$, p. 567), which means that training is the right of every employee of an Algerian company and it is guaranteed under in the law, and companies are obliged to undertake it annually.

1.3. Training process in the company. Training as an activity of human resources management passes by many steps, but the most important that can affect the efficiency of training is the determination of needs, we need to consider the activities involved, the duration of the training and the extent to which either employees or employers benefit from the process (G, Geoffrey T, \& LeslieT, 2019, p. 296), we will summarize the process in the next scheme: 


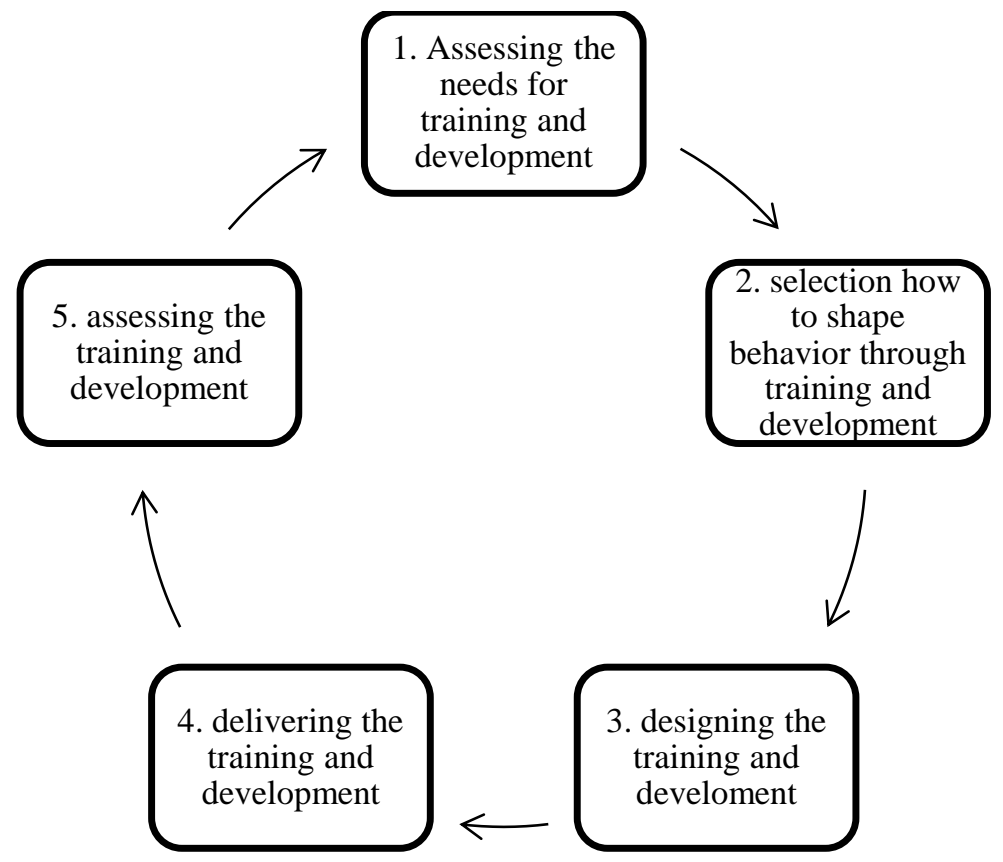

Figure 1. The training process

Source: (LUSSIER \& R.HENDON, 2019, p. 678).

1. Assessing the needs for training and development: as we said, this is the first step in the training process, it is important to determine the needs in order to treat the deviations in the level of efficiency and effectiveness of the employees, that's will orient company to do analysis on three levels (Wayne \& Martocchio, 2016, p. 215):

- Organizational analysis: it is the process of examining a company or organization to find ways of making it more effective (dictionary, 2021). This is has a relation with the goals determined by the organization, which is an general the improvement of the quality of the products and services presented by the company, in order to achieve a consumers satisfaction, not only outside but also and especially for the employees, that are constitute as a first consumer for the company.

- $\quad$ Task analysis: is the technique to use when there is a need to analyze the component of individual units of work.

(Jacobs, 2019, p. 82), in this phase company focuses on obtain an answer about what subjects should the training cover? So it must be there a description of the jobs that is we can say movement, and strategic, for example, the marketing, which helps to defines the products of the company, so it must put the all descriptions of the tasks, especially, the knowledge, skills, abilities ECT, to improve the performance and determine the descriptions required to occupy the posts.

- $\quad$ Person analysis: here company focuses on get an answer about who needs to be trained? That's according to the performance of the employees, and what are the competencies that company needs in the present and future, company looking for reducing the deviations and neutralize between acquire and require competencies.

The needs analysis pass by five basic steps (Garcarz \& Wilcock, 2005, p. 13):

The $\mathbf{1}^{\text {st }}$ step. gathering information by using interview and discussions with all actors of the organization, related with the current position, in the internal and external environment, determine the place that organization wants to be.

The $2^{\text {nd }}$ step. After collecting informations, company uses it to define the objectives, targets and standers required, 
The $3^{\text {rd }}$ step. Determine the basic skills and knowledge set required to deliver organizational the objectives.

The $4^{\text {th }}$ step. Compare this information with the identified training needs from staff appraisals, this step allows identifying the real needs of employees that organization should treat it

The $5^{\text {th }}$ step. Allocate resources and commission statutory and mandatory training by critically evaluating existing provision against the organization's definitions and standard.

1. Selection how to shape behaviour through training and development: after the determination the needs of training, comes the step of readiness for training for employee which means the desire and the ability to learn and acquire knowledge, through its self motivations, or due to the organization encouragement.

2. Designing the training and development : this step allows to determine the objectives of training programs, the topics, the trainers, the period of each topic, the place where the training will be, the methods of evaluation(hot evaluation/cold evaluation), and more important the budget of each program, this is rest an estimations for training.

3. Delivering the training and development: in this step company implements the program of training, which is real translation of the training plan, here the employees will acquire the skills, knowledge, we can say that the delivering the training also means transfer the knowledge, experiences to employees by trainers to be applied in the work, in other word this step where the behaviours will change.

4. Assessing the training and development : this is the last step in the process of training, this allows to measure the result that training made in the performance of trainees, through it the company can evaluate the effectiveness of training to know if the gap between the acquire competence and require competence is reduced and the deviations is corrected or not, that's what Browning has defined the evaluation as the process of first identifying and then quantifying or measuring the relationship between student (trainee) inputs and educational (training) outputs (Browning, 1970, p. 10). The evaluations can be hot evaluation, which is directly after the end of training, or cold evaluation that's means the company will evaluate the trainees after moments to know if the trainees obtain the objectives of training programs.

It should be noted that the process of analysing the training needs based on priority, it address the most important tasks that have a relationship with the main activity of the organization, which organization classifies its specific needs of needs according from the most important to the least.

\section{Career path: Definitions of the concepts}

Human resources management functions have been practiced in the organization for long periods of time, but are graded and evolved according to the needs and interests of the organizations, also we note that since the 1970s of the last century, there has been an increase in interest in studying the needs of employees and analyzing their career path in order to identify the stages of their lives and their career future. Career path development programs have been shown in many organizations in assisting employees, and in meeting their needs and requirements related to career growth and progression, as well as organizational needs and requirements. There are several authors and researchers in the field of management and sociology who have taken the subject of the career path in their researches, as (W.CARTER, W.COOK, \& W.DORSEY, 2009, pp. 19-20). when they defined the career path as the consequence of work positions or roles that a person holds over the span of a lifetime. These definitions give the career path the synonym of movement of the personal within organization. While (mahmoud, 2012, p. 7)، defined the career path that is the job positions that a person occupies during his working life, regardless of the extent of success or failure achieved by the individual, this definition takes into account the success of failure that made by the personal, which means the gap between his performance acquire and performance require in the case of failure, or when he achieved an advancement if he confirm that he is deserve to occupies the next position, in the case of success. Usually, the career path begins with a lower job which means at a lower administrative level, and ends up in a superior position, at a higher managerial level, through these levels, the employees occupies a several tasks, horizontally and vertically, that's it enables the employee to know his future career within organization, and allows him to define his career aspirations (akili, 2005, pp. 546-547). Through the previous 
definitions, we can conclude that career path is sum of the jobs, experiences and responsibilities that the employee assumes from entering the organization (recruitment) until retirement or the end of his work contract.

2.1. The importance of the career path. The career path plays a big role in the contemporary organization, its importance assembly both the organization and individuals, here we will develop it for each two actors, (HASSAN, 2005, p. 334):

- The importance of career path from individual view. one of the most important reason for the need for effective career path development is the problems and rapid changes and uncertainly, when as a result the success of career path and individuals satisfaction can be achieved when an individual understands himself well. And understands how he can anticipate changes in the environment, create opportunities for himself and learn from his mistakes, it is all the elements of effective career path development, in the light of privatization, small sizing and activities reduction, restructuring, the individual who has a self-vision of the opportunities and choices available to him, it is the individual who is better able to overcome obstacles to the growth of his career path, while the second reason for effective career path in the individual level is the specific nature of the contemporary individuals, which requires a high degree of control over their careers and personal lives. They are more active and ambitious individuals

- The importance of career path from organization view. The organization also like the individual has an incentive to understand the dynamics of the career path. Actually, the ability of the organization to manage its human resources effectively depends on its ability to understand an individual's job needs and help him mange his career effectively.

2.2. Career path development. Through the concepts presented on career path, which recognized that the career path is the sum of the jobs held by an employee during his career within organization. Career path development is also a continuous process, through which individual progresses through a set of stages in which each stage is characterized by a distinct set of characteristics, issues, problems and tasks (HASSAN, 2005, p. 340). This stages is presented by (almaghrabi, 2007, pp. 91-92-93), in the table below:

Table1. Stages of career path development and its characteristics.

\begin{tabular}{|l|l|l|l|l|}
\hline Characteristics & \multicolumn{1}{|c|}{$\begin{array}{c}\text { Curiosity and } \\
\text { exploration }\end{array}$} & $\begin{array}{c}\text { Establishment and } \\
\text { construction }\end{array}$ & \multicolumn{1}{c|}{$\begin{array}{c}\text { Maturation and } \\
\text { stability }\end{array}$} & \multicolumn{1}{|c|}{$\begin{array}{c}\text { Withdrawal and } \\
\text { retirement }\end{array}$} \\
\hline Tasks & $\begin{array}{l}\text { Identification of } \\
\text { interests and skills and } \\
\text { alignment of individual } \\
\text { potential with work } \\
\text { requirements }\end{array}$ & $\begin{array}{l}\text { Improvement and } \\
\text { growth, safety, } \\
\text { lifestyle development. }\end{array}$ & $\begin{array}{l}\text { Maintaining achievement } \\
\text { levels, updating and } \\
\text { developing skills. }\end{array}$ & $\begin{array}{l}\text { Retirement planning, } \\
\text { changes procedures to } \\
\text { the work-pension } \\
\text { balance. }\end{array}$ \\
\hline Activities & $\begin{array}{l}\text { Need for assistance; } \\
\text { Learning; } \\
\text { Direct positive trends. }\end{array}$ & $\begin{array}{l}\text { The tendency to be } \\
\text { independent and work } \\
\text { freely; } \\
\text { Launching of } \\
\text { Continuing } \\
\text { contributions. }\end{array}$ & $\begin{array}{l}\text { Training; } \\
\text { Care and security; } \\
\text { Policy formulation. }\end{array}$ & Launching out work. \\
\hline $\begin{array}{l}\text { The relationship } \\
\text { between other } \\
\text { employees }\end{array}$ & $\begin{array}{l}\text { Junior employee; } \\
\text { Recent practitioner. }\end{array}$ & $\begin{array}{l}\text { Fellow practitioner; } \\
\text { Helpful employee. }\end{array}$ & $\begin{array}{l}\text { Adviser and mentor; } \\
\text { Loyal guide. }\end{array}$ & $\begin{array}{l}\text { Includes others in his } \\
\text { care and education. }\end{array}$ \\
\hline Age & Less than 20 years old & 25-45 years old & 46-60 years old & \\
\hline Years of work & Within two years & 3-10 years & More than 10 years & More than 10 years \\
\hline
\end{tabular}

Source: (almaghrabi, 2007, pp. 91-92-93).

Through the above table, it is clear to us that the stages of career path development for employees in the organization pass like other stages of the life cycle, starting from the exploration stage to choosing the path and goals that they desire to achieve, usually the immediate post-employment period, then comes the stage of establishment after specifying the objectives pursued, and that's by starting up and building a specific view of their professional future, after that comes the stage of maturation and through it the career development takes 
place, and self realization, and it is the peak stage, which means achieve a new objectives within organization, finally the stage of withdrawal, which is the end of the career path of employee in the organization. It should be noted that the withdrawal does not necessarily mean retirement, but it can be also a change of work to another organization, fired from work, or reasons related to the organization itself, such as bankruptcy, merger.

\section{Presentation of the study and sample}

The stage of gathering data, after defining the questions and selecting the research sample, is considered the basis of the scientific research, this is due to the tools used to answer the problem posed, and thus it is possible to prove the validity of the hypothesis or their negation.

The object of our approach consists of analyze the role of the training; to constate its impact on career path of employees within the port enterprise OPE, we have determined the main axes of this activity to construct our questionnaire.

The choice of the research sample carries 50 employees, it included three departments, distributed as follows, 13 questionnaires distributed at the department of Human Resources fire from it for training center, 30 questionnaires distributed at the department of exploitation with its deferent services containers, export, informatics, 07 questionnaires distributed at department of captaincy. It turns out that $34 \%$ of them have experience between [0106[years, between [1-10[years and the experience of $28 \%$ which remains more than 10 years. Knowing that our simple contained of all socio-professional category which $24 \%$ of the sample are seniors executives, $30 \%$ are masteries, and $46 \%$ are executions, while the most of our sample have a university level in the rate of $64 \%$, and $34 \%$ have a secondary school, this help us to diagnostic the development of the competencies of employees in this enterprise, and constate the improvement of their career path through their work in the Oran Port Enterprise.

\section{The study results}

Table 2. The development of training process in Oran Port Enterprise from 2016 to 2020

\begin{tabular}{|l|c|c|c|c|c|}
\hline The year & 2016 & 2017 & 2018 & 2019 & 2020 \\
\hline $\begin{array}{l}\text { Number of } \\
\text { Human resources }\end{array}$ & 2359 & 2286 & 2254 & 476 & 2231 \\
\hline $\begin{array}{l}\text { Number of } \\
\text { trainees }\end{array}$ & 487 & 536 & $21.11 \%$ & $22.32 \%$ & 375 \\
\hline $\begin{array}{l}\text { The rate of } \\
\text { trainees } \\
\text { compared to } \\
\text { number of } \\
\begin{array}{l}\text { Human } \\
\text { Resources }\end{array}\end{array}$ & $20.64 \%$ & $23.44 \%$ & & & $16.80 \%$ \\
\hline
\end{tabular}

Source: elaborated by us from the internal documentations of Oran Port Enterprise.

Through the above table, we note that the number of trainees in Oran Port Enterprise has experienced slight decrease in the last three years, this is due to $01 \%$ of the wage mass determined by the department of finance and accounting for training budget, this rate of $01 \%$ designated by the Algerian legislator in the official gazette 90/11 related on work relations.

Through the data gathered, the $90 \%$ of responses of employees indicate that the employee needs to training to occupy their real job, which means training allows to define the basic elements of the jobs, and so put the right man in the right place, according to this result we can say training helps to identify the skills, abilities, knowledge of each employee in order to determine its job through describing the post requirements. 


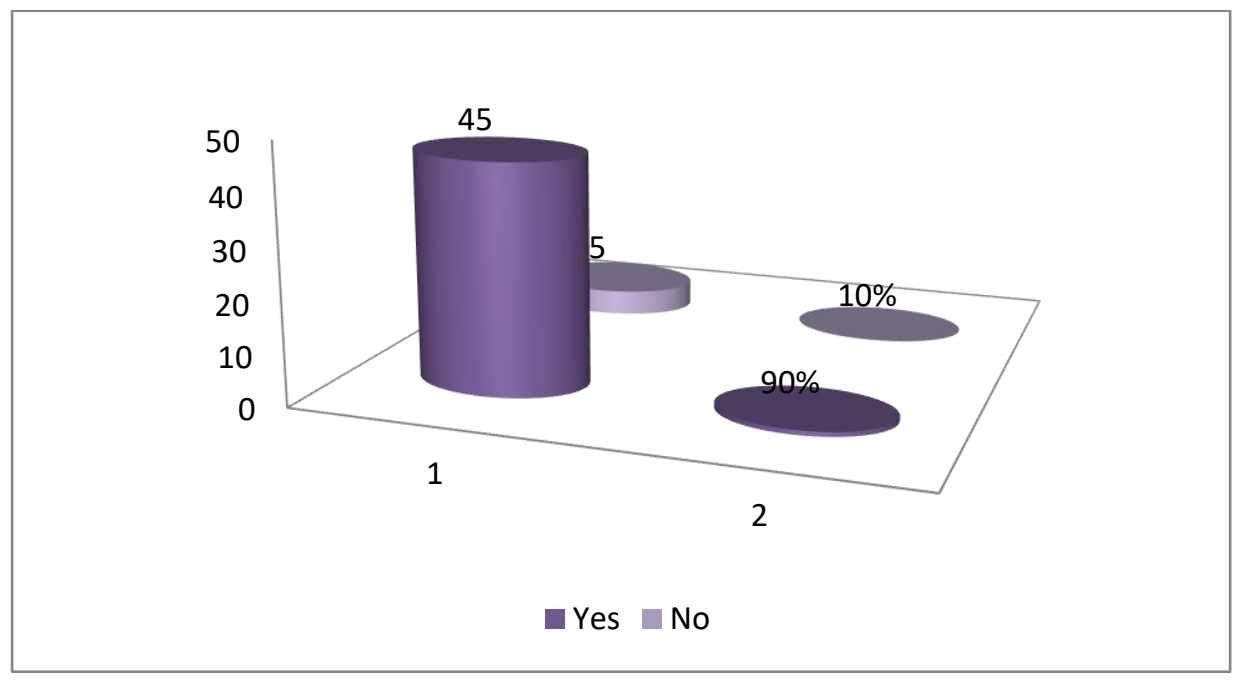

Figure 2. The need for training before placing an employee in his real position

Source: elaborated by authors from the data collected.

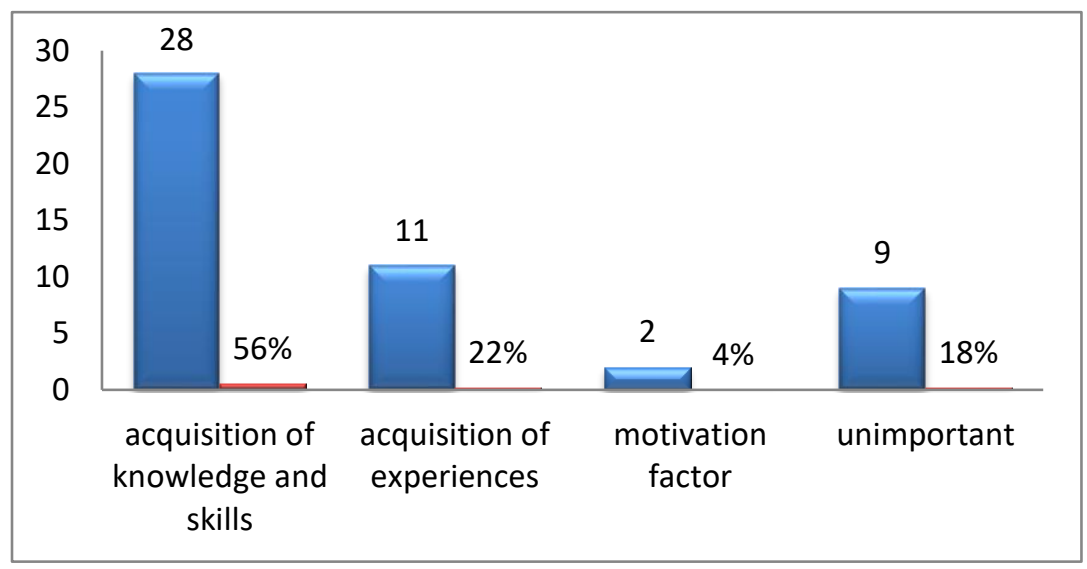

Figure 3. The meaning of training for employees

Source: elaborated by authors from the data collected.

The training at the level of the Oran Port Enterprise aims to acquire knowledge and skills to improve the performance in the exercise of tasks, that is allows to be up-to-date with the new mutations and transformations of the jobs, furthermore training helps to acquire experiences for technical jobs, The $56 \%$ of employees questioned indicate that the training oriented towards this aspect. While only $4 \%$ estimate that communication aims to motivate the employees, $18 \%$ from the sample answered that training is unimportant, that is makes us to think about the policy of training, to make sure that every employee contributes in the design of training plan, and the training must touches all socio-professional category.

Table 3. The contribution of training in the adaptation of employees' tasks

\begin{tabular}{|c|c|c|}
\hline \multicolumn{2}{|c|}{ Did training help you to adapt with the development of your task? } \\
\hline Yes & 50 & $100 \%$ \\
\hline No & 0 & $0 \%$ \\
\hline total & 50 & $100,00 \%$ \\
\hline
\end{tabular}

Source: elaborated by us from the data collected. 
The rate of $100 \%$ represent that training helps employees to adapt with their jobs, that is confirm that training allows to adapt with the environment changes, and the development of the tasks especially in the field of informations and communication technologies, but also to be up to date with the new legislations and laws in the different specialities.

\section{Did training help you to hold different posts and responsibilities in the company?}

$$
\text { yes no }
$$

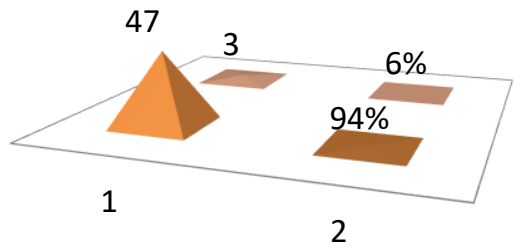

Figure 4. The contribution of training in the holding of new posts and responsibilities in the company

Source: elaborated by us from the data collected.

This result confirms that training contributes in the development of career path of employees by holding a responsibilities and posts, this can help the employee to occupying a different tasks especially in the case of absence of employee, so this allows work to continue without affecting the team work or stop the production, because the absence of employee, the rate of $94 \%$ answered that training help them.

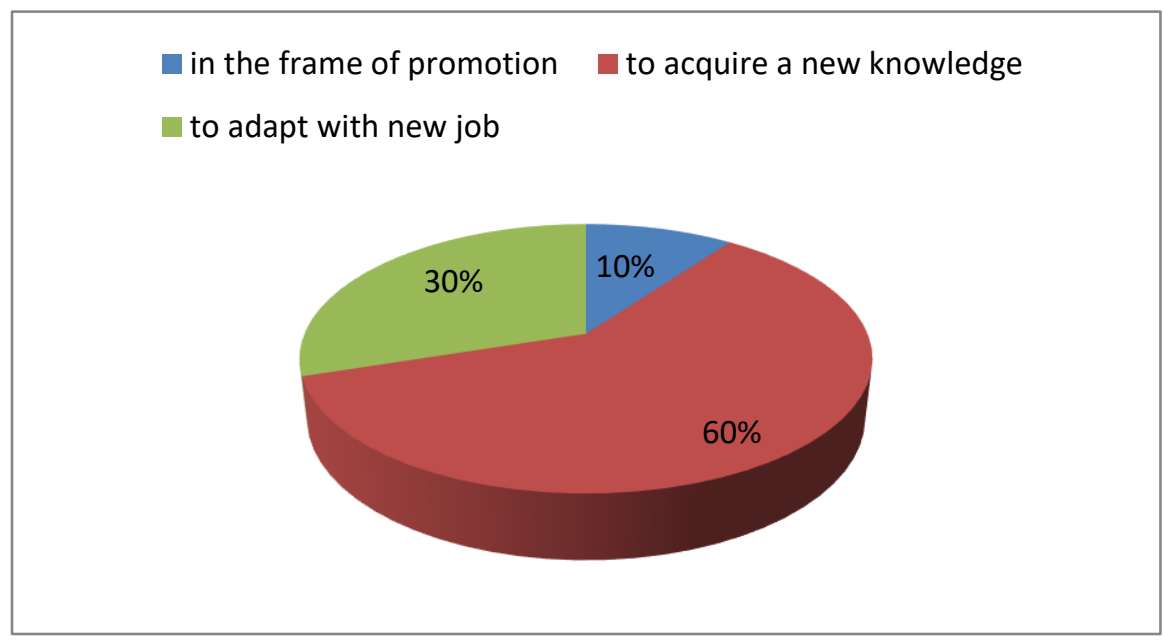

Figure 5. The object that made employee follow the training programs

Source: elaborated by us from the data collected.

Most of employees emphasized that they followed the training in order to acquire a new knowledge, that's way they answered that training means the acquirement of knowledge, $60 \%$ of them was agree with this idea, which allows to renewable the informations, and use it in situation of work. While 30\% answered that training is a tool to adapt with their new jobs, this permit to them to be up to date with the changes, furthermore, more than $40 \%$ of the sample said that they faced a problems when they occupied a new posts, in the case of internal or external recruitment, here we can say that training plays a big role to adjust the gap between the acquire competence and require competence, while $10 \%$ of our sample answered that they followed the training programs in the frame of promotion, that's prove that training is among the tools that can improve the career path of employees, through acquirement of experiences to apply it in the post of work. 
Table 4. The objectives of training

\begin{tabular}{|l|c|}
\hline The objectives of training in your company & Rates \\
\hline Increasing the efficiency of the employee & $98 \%$ \\
\hline Mastering the task & $98 \%$ \\
\hline Give a good image of the company & $96 \%$ \\
\hline Achieve the goals of the company & $92 \%$ \\
\hline Improvement the internal communication & $94 \%$ \\
\hline Increasing the capacity to accurately predict career path & $84 \%$ \\
\hline Job security & $92 \%$ \\
\hline Raising the professional skills & $98 \%$ \\
\hline An incentive to develop the career path & $92 \%$ \\
\hline Create a positive change of career trend for human resources & $96 \%$ \\
\hline Prepare a qualified employee & $98 \%$ \\
\hline
\end{tabular}

Source: elaborated by authors from the data collected.

The objectives of Oran Port Enterprise is to improve the efficiency and effectiveness of the employee in order to get them to mastering their tasks, by raising their professional skills, and prepare them to be a qualified employees, to occupy an new jobs and responsibilities, that allows them to be motivated to work better, furthermore, training aims to improve the internal communication, formal and informal, between all actors of the enterprise, and it create a positive change of career trend for human resources, all of these contributes to achieve the strategic goals of the company, as a result it can a core source to improve the image of the organization, and its reputation in the external environment and within enterprise according to $96 \%$ of responses confirm this.

\section{Analysis of the results}

This study confirm that training has a positive influence on the development of workers' trends, that's what shows in the dimension of training in improvement of career path, that's through the $96 \%$ approval rate, while training is necessary from the perspective of the staff, because it aims to enhance the performance of the employees, and it allows to adapt to organizational changes, the technological mutations, and cultural development, the percentage of $100 \%$ answered that training helps them to adapt with tasks development in different specialities.

Training contributes in increasing the employee skills in their career path management, it is clear from these results that we reached that training process is to provide an individual with the informations and knowledge that will earn him high competencies of performance, that's what shows the result of $98 \%$.

\section{Hypothesis discussion}

\section{The basic hypothesis:}

There is a correlation between training and career path, after analysing the straining in the company of Oran Port Enterprise, we emphasize the existence of intimate relationship between the career path and training, especially that our entire sample was trained, that shows that training is among important step in the company, so the hypothesis confirmed.

Training contributes to improving the career path of employees in the Algerian company in general, and in Oran Port Enterprise in particular, according to the results, some of employees confirm that they trained in the frame of promotion.

\section{The sub-hypothesis:}

Training contributes to the development of positive trends of workers towards work, so that training means acquiring knowledge and experience for employees, it is important tool for motivating, empowering, and improving the internal communication of the organization, thus creating an atmosphere of trust within organization, $56 \%$ of our sample answered that training allowing them to acquire a new knowledge and skills, while 92\% said that training is an incentive to develop the career path of employees, in addition, training contributes in improvement of the internal communication , 94\% from the sample answered that training improve the relationship between top down management, that's can create a good and healthy climate, building on 
collaboration and coordination between individuals, group and the team work whatever their graduations, or socio-professionals categories, so we can validate this hypothesis .

Training allows the development of employees' competency, in addition it affects their effectiveness and efficiency in carrying out the tasks entrusted to them, and as a result the development of their career path through promotion, assuming multiple positions and responsibilities, according to our sample answers, $94 \%$ of them confirmed that training contributes in the holding of new posts and responsibilities in the company, that's why they said that training allows to promotion, and to adapt with their new jobs, so this hypothesis is validated .

\section{Suggestions and recommendations:}

$>$ Involve all actors of different socio-professional categories in the process of designing the training plan, based on the principle of equal opportunities.

$>$ Determining the training needs accurately and according to priority in line with the requirements of the job position and developments in the field of jobs.

$>$ Sufficient period must be provided for the training of employees in order to obtain the greatest return on investment.

$>$ Reliance on training as a basis of professional promotion and the source of internal recruitment, thus reducing costs.

$>$ The trainees should transfer their gains through the training process of knowledge and experiences to their colleagues at work.

\section{Conclusion}

We are coming to develop the importance of training in the improvement of career path of employees in the organisation through our practical study in Oran Port Enterprise, not just in the technical aspects but also in the behaviours aspects, after collecting data, and constructing our questionnaire, which is included 50 employees from different department of the enterprise, and after analysing their answers about the questions in the field of training and its impact on their career paths, we can included that training has an important role in the career path improvement for employees, because it contributes in the development of competencies, and contributes in the increscent the ability of accurate prediction of career path of employees, it is also a major driver of change that's due to adapt with the transformations and changes in the world of works and jobs. While career path represent all the experiences obtained in the hall work period in the company, career path also helps employees to know their future career. We can say now that training is important station in the career path of employees in Oran Port Enterprise.

So, what we can be extracted from this study is to confirm the question, and confirm the hypothesis of this research, and this is the general objective of the study, after the research in this topic about the impact of training in the career path improvement for employees in the Algerian company, and expose the result, analyse it and discuss it.

The result of this study shows that training in Algeria is important that's why it is obliged. But the obligation of the training don't means that we must elaborate the training process just to avoid legal penalties, we should give the training process their place to develop the competencies, give the trainees the enough period to achieve the objective of training, make the training a source of promotion, transfer, motivation, this create a motivate employee who have the desire to develop their competencies in the company, and that's allows company to conserve the best employees and transfer their experiences to others.

As a conclusion, training in Algeria is still in the stage of reorganization and reconstruction, that's because the rapid mutations of the environment and legal aspects obliged to try adapt with changes, also and especially in the technological field, and knowledge economic. The human resources rest the only resource that can create the added value for company and the country. So the enterprises should interest about the employees and its important in the company that by develop them and motivate them in addition to follow them in order to put the right man in the right place this permit to companies to rest survive, and achieve their goals. 
Funding: self-funded.

Author contribution: conceptualization, Bessaim, R., Gadi, I.; data curation, Bessaim, R., Gadi, I.; formal analysis, Bessaim, R., Gadi, I.; funding acquisition, Bessaim, R., Gadi, I.; investigation, Bessaim, R., Gadi, I.; methodology, Bessaim, R., Gadi, I.; project administration, Bessaim, R., Gadi, I.; resources, Bessaim, R., Gadi, I.; software, Bessaim, R., Gadi, I.; supervision, Bessaim, R., Gadi, I.; validation, Bessaim, R., Gadi, I.; visualization, Bessaim, R., Gadi, I.; writing - original draft, Bessaim, R., Gadi, I.; writing - review \& editing, Bessaim, R., Gadi, I.

\section{References}

1. Achouch, M., Alsaid, A., \& Nafsia, B. (2017). The Basics Of Human Resources Management. Cairo. Available at: [Link].

2. Akili, A. W. (2005). Human resources management a strategic dimension. Aman: Wail House. Available at: [Link].

3. Alhitti, K. (2005). Human resourves management strategic introduction. Aman: Wail House. Available at: [Link].

4. Almaghrabi, A. A. (2007). Modern trends in the study and practices of human resources management. Available at: [Link].

5. Altaani, H. (2007). Modern Administrative Training. Aman: Almaseera House. Available at: [Link].

6. Browning, P. L. (1970). Evaluation of short-term training. Oregon: Oregon Univ. Available at: [Link].

7. Buckley, R., \& Caple, J. (2009). The Theory And Practice Of Training. London: British Library Cataloguing In Publication Data. Available at: [Link].

8. Chararah, M. (2019). Modern Trends And Roles. In Human Resources Management. Available at: [Link].

9. Dessler, G. (2017). Human Resources Management. USA: Pearso Education. Available at: [Link].

10. Dessler, G. (2020). Human Resources Management. Florida: Pearson. Available at: [Link].

11. Dictionary, C. (2021). Organizational Analysis. UK, Cambridge University Press. Available at: [Link].

12. Elblouchi, B. (2017). Strategic Planing And Human Capital In Media Organizationde. Cairo: Arab Knowledge Bureau. Available at: [Link].

13. G, D., Geoffrey T, W., \& Leslie T. S. (2019). Human Resources Management A Critical Approach. New York: Routledge Taylor and Francis Group. Available at: [Link].

14. Gambo, H. S. (2015). The impact of trainng and development on workers' productivity. Review of Public Administration and Management, 2. Available at: [Link].

15. Garcarz, W., \& Wilcock, E. (2005). Statutory and Manddatory Training in Health and Social care. Oxford: Taylor and Francis group. Available at: [Link].

16. Hassan, R. (2005). Strategic Introduction To Human Resources Planning And Development. The University House. Available at: [Link].

17. Ivan Cevich, J. (1995). Human Resources Management. Irwin Inc. Available at: [Link].

18. Jacobs, R. L. (2019). Work Analysis In The Knowledge Economy. Cham, Switzerland: Springer. Available at: [Link].

19. Lussier, R. N., \& R. Hendon, J. (2019). Human Resources Management Function, Application, And Skill Development. California: Sage Publications. Available at: [Link].

20. Mahmoud, A. A. (2012). Career Future In The Light Of Training Competencies. Cairo: Arab Group. Available at: [Link].

21. Mounir, N. (2014). Human Resources Management. Chelef: University Publications Algeria. Available at: [Link].

22. Muslim, M. (2007). Introduction To Work Psychologie. Kortuba Publication. Available at: [Link].

23. Nassr, M. A. (2017). Distance Training Is Your Gateway To A Better Future. Cairo: Arab Group. Available at: [Link].

24. Nassr, M. A. (2016). Games And Training Matches To Develop The Training Profession. Cairo: Arab Group. Available at: [Link]. 
25. Noe, R. A., R. Hollenbeck, J., Gerhart, B., \& Wright, P. M. (2016). Fundamentals of Human Resources Management. New York: McGraw-Hill Education. Available at: [Link].

26. Others, M. K. (2018). Human Resources Management. Cairo. Available at: [Link].

27. W. Carter, G., W. Cook, K., \& W. Dorsey, D. (2009). Career Paths Charting Courses To Success For Organizations And Their Employees. Oxford, UK: Wiley-Blackwell. Available at: [Link].

28. Wayne, R., \& Martocchio, J. J. (2016). Human Resources Management. London: Pearson Education. Available at: [Link].

29. Werther, B. (1982). Personal Management and Huaman Resources. New york: McGraw-Hill. Available at: [Link].

30. Wilkinson, A., Redman, T., \& Dundon, T. (2017). Contemporary Human Resources Managementtext And Cases. Harlow: Pearson Education. Available at: [Link].

31. 90/11, O. G. (1990). Employement Relationship Law 90/11. Official Gazette (17), 567. Available at: [Link]. 